\title{
Vitamin a supplementation and other predictors of anemia among children from Dar Es Salaam, Tanzania.
}

\section{Citation}

Villamor, E, D Spiegelman, R Mbise, W W Fawzi, and G Ndossi. 2000. "Vitamin A Supplementation and Other Predictors of Anemia among Children from Dar Es Salaam, Tanzania." The American Journal of Tropical Medicine and Hygiene 62 (5): 590-97. https://doi.org/10.4269/ ajtmh.2000.62.590.

\section{Permanent link}

http://nrs.harvard.edu/urn-3:HUL.InstRepos:41384734

\section{Terms of Use}

This article was downloaded from Harvard University's DASH repository, and is made available under the terms and conditions applicable to Other Posted Material, as set forth at http:// nrs.harvard.edu/urn-3:HUL.InstRepos:dash.current.terms-of-use\#LAA

\section{Share Your Story}

The Harvard community has made this article openly available.

Please share how this access benefits you. Submit a story.

\section{Accessibility}




\title{
VITAMIN A SUPPLEMENTATION AND OTHER PREDICTORS OF ANEMIA AMONG CHILDREN FROM DAR ES SALAAM, TANZANIA
}

\author{
EDUARDO VILLAMOR, ROGER MBISE, DONNA SPIEGELMAN, GODWIN NDOSSI, AND WAFAIE W. FAWZI \\ Departments of Nutrition and Epidemiology, Harvard School of Public Health, Boston, Massachusetts; Department of Pediatrics \\ and Child Health, Muhimbili University College of Health Sciences, Dar es Salaam, Tanzania; Department of Biostatistics, \\ Harvard School of Public Health, Boston, Massachusetts; Tanzania Food and Nutrition Center, Dar es Salaam, Tanzania
}

\begin{abstract}
The associations of hemoglobin, hematocrit, and packed cell volume with socioeconomic factors, malaria, human immunodeficiency virus (HIV) infection, and nutritional status were examined among 687 children admitted to hospital with pneumonia participating in a double blind, placebo-controlled trial of vitamin A supplementation. Children were randomized to receive 2 doses of vitamin A (200,000 IU) or placebo at baseline, and additional doses at 4 and 8 months after discharge from hospital. Hemoglobin levels were measured at enrollment and, on a subset of 161 children, during follow-up. At baseline, hemoglobin concentration was positively associated with the number of possessions in the household, maternal level of education and quality of water supply, and inversely related to malaria infection after controlling for potential confounding variables. Children infected with HIV experienced a significant fall in mean hemoglobin levels over time. The risk of developing severe anemia $(<7 \mathrm{~g} /$ $\mathrm{dL}$ ) during follow-up was lower for children who were breastfed for longer than 18 months as compared to those with less than 6 months of breastfeeding (adjusted prevalence ratio $=0.14,95 \%$ confidence interval $[\mathrm{CI}]=0.02$, 0.93; $P=0.04$ ), and higher for children over two years of age as compared to 6 to 11 months-old infants (adjusted prevalence ratio $=8.11,95 \% \mathrm{CI}=1.2,55.8 ; P=0.03$ ). Children with repeated diagnoses of malaria had 4.1 times the risk of developing severe anemia than did children without the diagnosis $(95 \% \mathrm{CI}=1.3,13.5 ; P=0.02)$. Vitamin A supplements were associated with an overall nonsignificant reduction of $14 \%$ in the risk of developing severe anemia (adjusted prevalence ratio $=0.86,95 \% \mathrm{CI}=0.37,1.99 ; P=0.73$ ). We conclude that malaria, HIV infection, low socioeconomic status, and short duration of breastfeeding are strong and independent determinants of adverse hematologic profiles in this population.
\end{abstract}

\section{INTRODUCTION}

The prevalence of anemia in the developing world is still extremely high. In Africa, $33 \%$ of children below age 4, $52 \%$ of children from 5-14 years, and $47 \%$ of pregnant women have hemoglobin levels below the established adequate cutoff points: 11,12 , and $11 \mathrm{~g} / \mathrm{dL}$, respectively. ${ }^{1}$ Commonly, anemia is the more severe manifestation of iron deficiency. ${ }^{2}$ However, its determinants vary across cultural and geographic settings. ${ }^{3}$ In many parts of sub-Saharan Africa, for example, malaria infection accounts for a large proportion of severe anemia among children, ${ }^{4}$ but in others, the marginal intake of foods rich in iron is still the most likely cause of anemia. ${ }^{5}$ Most of the studies on the determinants of anemia are cross-sectional surveys that fail to differentiate the temporality of the associations between exposure and outcome. Longitudinal designs, such as the one presented here, are more appropriate for identifying specific risk factors that would allow targeting of interventions aimed at reducing the burden of anemia in children.

The coexistence of multiple micronutrient deficiencies may elevate the risk of developing anemia. There is an increasing body of evidence from observational and intervention studies suggesting a positive biological relationship between vitamin A status and iron metabolism, ${ }^{6}$ although the specific mechanisms remain unknown. Administration of vitamin A to anemic children ${ }^{7,8}$ and pregnant women ${ }^{9}$ has resulted in improvements of hematologic parameters and recovery from anemia. Thus, vitamin A supplementation of anemic populations could be an effective, low cost intervention for improving hemoglobin concentrations. ${ }^{10}$ There are limited data on trials from sub-Saharan Africa addressing the effect of vitamin A on the hematological status of children. Moreover, the potential interactions between other determi- nants of anemia and the administration of vitamin A remain unclear. We examined the cross-sectional and longitudinal associations between sociodemographic and health-related predictors of hemoglobin, as well as the effect of vitamin A supplements on the risk of anemia in preschool children from Dar es Salaam, Tanzania.

\section{MATERIALS AND METHODS}

The Tanzania Vitamin A Study was a randomized, doubleblind, placebo-controlled trial conducted between April 1993 and March 1997 among 687 children 6 to 60 months of age who were admitted with pneumonia to Muhimbili Medical Center in Dar es Salaam. The trial design has been described elsewhere. ${ }^{11,12}$ Briefly, children were enrolled to determine the effect of vitamin A on severity of infection during hospital stay. Pneumonia was diagnosed by a pediatrician if children presented with cough and one or more of the following signs: respiratory rate $\geq 40$ breaths (50 breaths for infants below one year of age) per minute, chest retractions, inability to eat or drink, decreased air entry, crackling sounds, or dullness to percussion. Exclusion criteria were: presence of eye signs and symptoms of vitamin A deficiency, intake of vitamin A supplements in the preceding 4 months, weight-for-age less than $60 \%$ of the reference median, measles, pulmonary tuberculosis, diphteria, and whooping cough. In-hospital treatment of pneumonia was provided according to the standard of care in Tanzania. Children were followed for at least one year after discharge from hospital for survival, health, and growth endpoints. Informed consent was granted by the mother or primary caretaker of the child. The protocol was approved by the Research and Publications Committee of Muhimbili University College of Health Sciences, the Research and Ethics Committee of Tanzania Food 
and Nutrition Center, and the Human Subjects Committee of The Harvard School of Public Health.

The participants were randomly assigned to receive four oral doses of either 200,000 IU of vitamin A and 40 IU of vitamin $\mathrm{E}$ or placebo (40 IU of vitamin E only). Half of this dose was given to children aged $<1$ year. The first dose was administered on the day of admission and the second on the following day. The third and fourth doses were given at four and eight months respectively after discharge from hospital. Compliance with the first two doses was virtually $100 \%$, since they were administered in the hospital by a research supervisor. The two remaining doses were given at a study clinic where mothers and children presented during follow-up. Seventy-five percent of the children were given the third dose and $74.2 \%$ received the fourth. Laboratory assays of the vitamin A solution yielded $95 \%$ potency after 2 years of field storage.

Information collected at baseline included feeding practices, immunizations, and sociodemographic characteristics such as the parents' level of education, number of siblings, water and sanitary conditions in the household, and possessions available at home (radio, television, bicycle, car, and refrigerator). Height (or length in children $<2$ years of age) and weight were measured on the first day of hospital admission by trained personnel using standard techniques and calibrated instruments. A blood specimen was drawn from all children at baseline. At 4 and 8 months, concurrent with the administration of the third and fourth doses, authorization was granted from a subset of the mothers to obtain additional blood samples from their children. Hemoglobin, packed cell volume, and red cell counts were determined by standard techniques. ${ }^{13}$ Plasmodium falciparum malaria was assessed by thick and thin blood smears. The latest blood specimen available for each child was tested for human immunodeficiency virus (HIV) antibodies using ELISA (Murex Biotech Ltd, Dartford, UK), and confirmed by Western Blot (Biorad Laboratories, Ltd, Hertfordshire, UK). Infection with HIV among children younger than 15 months with positive or undetermined results was also tested using heat-denatured HIV-p24 antigen assays with confirmatory neutralization assays (Dupont, Wilmington, DE).

In a cross-sectional analysis of 617 children in whom a full blood picture was obtained at recruitment, we studied the relationships between baseline hemoglobin concentration and socioeconomic status, malaria and HIV diagnoses, breastfeeding, and nutritional status. Differences among medians of hematological parameters across levels of the covariates were tested using Wilcoxon rank sum and KruskalWallis tests. A linear regression model for hemoglobin was fitted including the independent variables that were significant predictors in the univariate analysis $(P<0.20)$ and those considered relevant from the biological point of view.

The subset of 161 children who had blood pictures at both baseline and follow-up did not differ from the entire study population at baseline in terms of their sociodemographic characteristics, health status, or assignment to treatment. Distribution of potential confounders between vitamin A and placebo groups was compared in the follow-up subsample. We conducted intent-to-treat analyses to examine the effect of supplements on hemoglobin levels over time using mixed effects regression models. ${ }^{14}$ Hemoglobin at baseline and at
4 and 8 months was introduced as the dependent variable and vitamin A supplementation, sociodemographic variables, HIV status, and malaria infection as predictors. Robust estimators of variance ${ }^{15}$ were used in the regression models.

Severe anemia was defined as a hemoglobin level below $7 \mathrm{~g} / \mathrm{dL} .{ }^{16}$ This corresponds to the $25^{\text {th }}$ percentile of the hemoglobin distribution in our study population. The effect of vitamin A supplements and other variables on severe anemia at either 4 or 8 months was studied using the latest value available as the follow-up endpoint. Prevalence ratios and 95\% confidence intervals of anemia at follow-up were estimated by binomial regression with the log link function. ${ }^{17}$ The likelihood ratio test was employed to determine whether treatment effects were significantly different across strata of potential modifiers. Data were analyzed with the Statistical Analyses System software (SAS Institute Inc., Cary, NC).

\section{RESULTS}

Sociodemographic characteristics did not differ significantly by treatment group at baseline (Table 1). Mean hemoglobin level was $8.5 \mathrm{~g} / \mathrm{dL}(\mathrm{SD}=2.3)$. About $40 \%$ of children were below the age of one year. In the follow-up subsample, children on placebo were more likely to be male, younger, with less educated mothers, fewer belongings, and slightly shorter duration of breastfeeding. Mean hemoglobin at the latest follow-up visit was $9.4 \mathrm{~g} / \mathrm{dl}(\mathrm{SD}=1.7)$. The prevalence of malaria was $26 \%$ at enrollment and $23 \%$ at the last visit.

Determinants of hemoglobin, packed cell volume and red cell count at baseline are presented in Table 2. Hemoglobin was positively associated with child's age, and with indicators of the household's socioeconomic status. Mean hemoglobin of children whose mothers had secondary schooling was $1.7 \mathrm{~g} / \mathrm{dL}$ higher than that of children whose mothers had no primary schooling $(P<0.001)$. Hemoglobin was also significantly higher among children from households with more possessions and better quality of water supply. Duration of breastfeeding at baseline was also positively related, albeit not significantly, to the hemoglobin levels. Mean hemoglobin concentration of children diagnosed with malaria was $1.4 \mathrm{~g} / \mathrm{dL}$ - significantly lower than among those without malaria. Hemoglobin, packed cell volume, and red cell count were positively associated with the mother's level of education, number of possessions and quality of water, and inversely related to malaria. The child's HIV status was not a significant predictor of hemoglobin levels at enrollment.

In analysis adjusted for sex, age, duration of breastfeeding, and socioeconomic variables, malaria infection was a strong predictor of hemoglobin level at the first visit (Table $3)$. The difference in mean hemoglobin between children with or without malaria diagnosis was comparable to that found in unadjusted analysis $(1.3 \mathrm{~g} / \mathrm{dL}$ higher in children free of the disease, $95 \% \mathrm{CI}=-1.74,-0.88)$. Children of mothers with a secondary level of education or from households with two or more possessions had significantly higher hemoglobin concentrations than those of mothers with the lowest level of education or households with no possessions, respectively. Better household water supply was also associated with increased hemoglobin level. Children from dwellings with tap water had, on average, $1.2 \mathrm{~g} / \mathrm{dL}$ higher 
TABLE 1

Characteristics of the study population at baseline in vitamin A and placebo arms

\begin{tabular}{|c|c|c|}
\hline & $\begin{array}{l}\text { Placebo } \\
\text { no. (\%) }\end{array}$ & $\begin{array}{c}\text { Vitamin } \mathrm{A} \\
\text { no. }(\%)\end{array}$ \\
\hline No. randomized & 307 & 310 \\
\hline \multicolumn{3}{|l|}{ Sex } \\
\hline Female & $135(44.3)$ & $141(45.6)$ \\
\hline Male & $170(55.7)$ & $168(54.4)$ \\
\hline \multicolumn{3}{|l|}{ Child's age (months) } \\
\hline $6-11$ & $137(44.6)$ & $123(39.7)$ \\
\hline $12-23$ & 98 (31.9) & $115(37.1)$ \\
\hline$\geq 24$ & $72(23.4)$ & $72(23.2)$ \\
\hline Mother is literate* & $264(86.0)$ & $273(88.0)$ \\
\hline \multicolumn{3}{|l|}{ Mother's education } \\
\hline Low† & $51(16.6)$ & $46(14.8)$ \\
\hline Elementary & $231(75.2)$ & $249(80.3)$ \\
\hline Secondary & $25(8.1)$ & $15(4.8)$ \\
\hline \multicolumn{3}{|l|}{ Mother's occupation } \\
\hline Housewife & $234(76.2)$ & $219(70.7)$ \\
\hline Petty trader & $52(16.9)$ & $60(19.4)$ \\
\hline Messenger/clerk & $7(2.3)$ & $9(2.9)$ \\
\hline Professional & $7(2.3)$ & $9(2.9)$ \\
\hline Other & $7(2.3)$ & $13(4.2)$ \\
\hline \multicolumn{3}{|l|}{ Mother's parity } \\
\hline No previous births & $88(29.2)$ & $96(31.4)$ \\
\hline $1-2$ & $124(41.2)$ & $133(43.5)$ \\
\hline $3-4$ & 63 (20.9) & $56(18.3)$ \\
\hline$\geq 5$ & $26(8.6)$ & $21(6.9)$ \\
\hline \multicolumn{3}{|l|}{$\begin{array}{l}\text { Household number } \\
\text { of possessions } \ddagger\end{array}$} \\
\hline 0 & $47(15.3)$ & $34(11.0)$ \\
\hline 1 & $142(46.3)$ & $161(51.9)$ \\
\hline$\geq 2$ & $118(38.4)$ & $115(37.1)$ \\
\hline \multicolumn{3}{|l|}{ Water supply } \\
\hline Tap in house & $52(16.9)$ & $52(16.8)$ \\
\hline Tap in compound & $86(28.0)$ & $91(29.4)$ \\
\hline Tap outside compound & $151(49.2)$ & $154(49.7)$ \\
\hline Public well & $18(5.8)$ & $13(4.2)$ \\
\hline \multicolumn{3}{|l|}{$\begin{array}{l}\text { Duration of breastfeeding } \\
\text { (months) }\end{array}$} \\
\hline $0-6$ & $50(16.3)$ & $41(13.3)$ \\
\hline $7-12$ & $110(35.8)$ & $117(37.9)$ \\
\hline $13-18$ & $78(25.4)$ & $78(25.2)$ \\
\hline$\geq 19$ & $69(22.5)$ & $73(23.6)$ \\
\hline \multicolumn{3}{|l|}{ Child's nutritional status } \\
\hline Stunted & $62(22.2)$ & $73(25.3)$ \\
\hline Wasted & $42(15.1)$ & $36(12.5)$ \\
\hline Stunted and wasted & $9(3.2)$ & $12(4.2)$ \\
\hline Malaria prevalenceII & $63 / 258(24.4)$ & $72 / 266(27.1)$ \\
\hline HIV positive & $23 / 294(7.8)$ & 29/301 ( 9.6) \\
\hline
\end{tabular}

* Ability to read a sentence.

Low education includes mothers with no education and those who attended Koranic school or adult education classes.

$\$$ Radio, television, car, bicycle, and refrigerator.

\$ Radio, television, children were below $-2 \mathrm{z}$-scores in weight-for-age, stunted children were below $-2 \mathrm{z}$-scores (National Center for Health Statistics reference) in height-for-age. If Presence of malaria parasites in thick and thin blood smears.

\# HIV = human immunodeficiency virus.

hemoglobin than children whose mothers used public wells (95\% CI $=0.19,1.87 \mathrm{~g} / \mathrm{dL})$. Duration of breastfeeding was positively associated with hemoglobin at baseline, although this relationship was not statistically significant.

Vitamin A supplementation resulted in a non-significant, average increase of $0.19 \mathrm{~g} / \mathrm{dL}$ in hemoglobin levels per visit, after adjusting for sex, age, number of household possessions, HIV status, and malaria, in a longitudinal regression model for repeated measurements of hemoglobin. Children with malaria at baseline had a hemoglobin concentration that was, on average, $1.38 \mathrm{~g} / \mathrm{dL}$ lower than that of children with a negative blood smear $(95 \% \mathrm{CI}=-1.79,-0.97 \mathrm{~g} / \mathrm{dL} ; P$ $<0.01)$. Over time, there was a significant increase in hemoglobin levels, which was higher among children with malaria at the first visit than in those free of the infection (1.13 $\mathrm{g} / \mathrm{dL}$ per visit versus $0.31 \mathrm{~g} / \mathrm{dL}$ per visit). Hemoglobin levels at any visit were, on average, $1.30 \mathrm{~g} / \mathrm{dL}$ lower $(95 \% \mathrm{CI}=$ $-1.66,-0.94 \mathrm{~g} / \mathrm{dL} ; P<0.01)$ among children with malaria diagnosis at that same visit than in children without parasites in their blood smears. The short-term change in hemoglobin during any four-month interval between two visits was significantly influenced by the child's HIV status and the hemoglobin level at the beginning of the particular interval. Hemoglobin change was higher among children with lower levels at the beginning of the interval. HIV-positive children had an average $0.8 \mathrm{~g} / \mathrm{dL}$ decrease in hemoglobin levels during any four-month interval $(95 \% \mathrm{CI}=0.09,1.49 \mathrm{~g} / \mathrm{dL} ; P$ $=0.03$ ).

The overall prevalence of severe anemia (hemoglobin below $7.0 \mathrm{~g} / \mathrm{dL}$ ) at the last follow-up visit was $10.6 \%$. Adjusted prevalence ratio (PR) estimates for anemia by several predictors are presented in Table 4. Children older than two years of age were at a higher risk of anemia than children below one year (Prevalence Ratio $=8.1,95 \% \mathrm{CI}=1.2$, 55.8; $P$ value, test for trend $=0.03$ ). Children with malaria diagnosis at both baseline and follow-up visits had a 4.1 times higher risk of anemia as compared to children who never had malaria. Children who had malaria at baseline but not at follow-up had the lowest risk for anemia in the last visit. Breastfeeding was associated with lower risk of anemia: children who had been breastfed for more than 18 months at the time of enrollment had a large and significant reduction in their risk of developing severe anemia during the follow-up period when compared to children who had been breastfed for six months or less $(\mathrm{PR}=0.14,95 \% \mathrm{CI}$ $=0.02,0.93 ; P$ value, test for trend $=0.04)$.

Overall, vitamin A supplementation was associated with a non-significant $14 \%$ reduction in the risk of developing severe anemia $(\mathrm{PR}=0.86,95 \% \mathrm{CI}=0.37,1.99)$. We examined the effect of the supplements by strata of some other predictors (Table 4). There was a borderline significant interaction between treatment and anemia at baseline $(P=$ 0.07). Among children with severe anemia at the first visit, vitamin A had a protective effect against the risk of having anemia by the end of follow-up (PR $=0.27 ; 95 \% \mathrm{CI}=0.03$, 2.19; $P=0.22$ ).

\section{DISCUSSION}

Few studies have addressed the determinants of longitudinal changes in hemoglobin levels and anemia risk in a pediatric population with high prevalence of both malaria and HIV infection. We conducted cross-sectional and longitudinal analyses for the predictors of hemoglobin and severe anemia in preschool Tanzanian children who participated in a randomized clinical trial of vitamin A supplementation.

Malaria infection and low socioeconomic status, as measured by the level of maternal education, the number of possessions in the household, and the quality of water supply were strong determinants of low hemoglobin concentration at first visit. In addition, shorter duration of breastfeeding, 
TABLE 2

Univariate relationships of child and maternal characteristics and hematologic indicators at baseline

\begin{tabular}{|c|c|c|c|c|}
\hline & No. $(\%)$ & $\begin{array}{l}\text { Mean chemoglobin } \\
\text { g/dL (SD) }\end{array}$ & $\begin{array}{l}\text { Mean packed } \\
\text { cell volume } \\
\%(\mathrm{SD})\end{array}$ & $\begin{array}{l}\text { Mean red cell } \\
\text { count } \times 10^{6 / \mu l} \\
(\mathrm{SD})\end{array}$ \\
\hline \multicolumn{5}{|l|}{ Sex } \\
\hline Female & $276(45)$ & $8.7(2.2)$ & $26.1(6.7)$ & $3.67(1.05)$ \\
\hline Male & $338(55)$ & $8.5(2.3)$ & $25.6(6.3)$ & $3.67(0.98)$ \\
\hline \multicolumn{5}{|l|}{ Child's age (months) } \\
\hline $6-11$ & $260(42)$ & $8.4(2.1)$ & $25.4(6.3)$ & $3.63(1.00)$ \\
\hline $12-23$ & $213(35)$ & $8.4(2.1)$ & $25.6(6.0)$ & $3.76(1.00)$ \\
\hline$\geq 24$ & $144(23)$ & $9.1(2.5)^{*}$ & $26.8(7.4)$ & $3.59(1.04)$ \\
\hline \multicolumn{5}{|l|}{ Mother is literateII } \\
\hline No & $80(13)$ & $8.7(2.2)$ & $26.0(6.4)$ & $3.60(0.95)$ \\
\hline Yes & $537(87)$ & $8.5(2.2)$ & $25.7(6.5)$ & $3.68(1.02)$ \\
\hline \multicolumn{5}{|l|}{ Mother's education } \\
\hline LowdI & $97(16)$ & $8.6(2.3)$ & $26.1(6.1)$ & $3.62(0.93)$ \\
\hline Elementary & $480(78)$ & $8.4(2.2)$ & $25.4(6.3)$ & $3.63(1.02)$ \\
\hline Secondary & $40(6)$ & $10.3(2.0) \dagger$ & $30.1(6.6) \dagger$ & $4.29(0.87) \dagger$ \\
\hline \multicolumn{5}{|l|}{ Mother's occupation } \\
\hline Housewife & $453(73)$ & $8.5(2.2)$ & $25.7(6.5)$ & $3.65(1.02)$ \\
\hline Petty trader & $112(18)$ & $8.2(2.1)$ & $25.2(6.0)$ & $3.64(0.94)$ \\
\hline Messenger/clerk & 16 ( 3) & $9.5(2.7)$ & $28.7(8.1)$ & $3.84(1.27)$ \\
\hline Professional & $16(3)$ & $9.3(1.9) \ddagger$ & $27.8(5.6)$ & $3.67(0.93)$ \\
\hline Other & $20(3)$ & $9.6(2.0)$ & $28.5(6.5)$ & $4.08(0.88)$ \\
\hline \multicolumn{5}{|l|}{ Mother's parity } \\
\hline No previous births & $184(30)$ & $8.5(2.3)$ & $25.4(6.7)$ & $3.61(1.08)$ \\
\hline $1-2$ & $257(42)$ & $8.6(2.2)$ & $25.8(6.5)$ & $3.70(1.00)$ \\
\hline $3-4$ & $119(20)$ & $8.3(2.3)$ & $25.8(6.1)$ & $3.65(0.94)$ \\
\hline$\geq 5$ & 47 ( 8) & $9.0(2.0)$ & $27.0(6.3)$ & $3.74(0.93)$ \\
\hline \multicolumn{5}{|l|}{ Household possessions } \\
\hline None & $81(13)$ & $7.7(2.2)$ & $23.2(6.7)$ & $3.21(1.02)$ \\
\hline 1 & $303(49)$ & $8.4(2.2)$ & $25.4(6.2)$ & $3.62(0.99)$ \\
\hline$\geq 2$ & $233(38)$ & $9.0(2.3) \dagger$ & $27.0(6.4) \dagger$ & $3.88(0.98) \dagger$ \\
\hline \multicolumn{5}{|l|}{ Water supply } \\
\hline Tap in house & $104(17)$ & $9.2(2.3)$ & $27.7(6.7)$ & $3.99(1.00)$ \\
\hline Tap in compound & 177 (29) & $8.4(2.1)$ & $25.6(6.1)$ & $3.78(0.97)$ \\
\hline Tap outside compound & $305(49)$ & $8.5(2.2)$ & $25.6(6.3)$ & $3.57(0.99)$ \\
\hline Public well & $31(5)$ & $7.2(2.3) \dagger$ & $21.7(7.3)^{*}$ & $2.97(1.03) \dagger$ \\
\hline \multicolumn{5}{|l|}{ Breastfeeding (months) } \\
\hline $0-6$ & $91(15)$ & $8.4(2.5)$ & $24.9(6.5)$ & $3.44(0.97)$ \\
\hline $7-12$ & $227(37)$ & $8.4(2.1)$ & $25.5(6.2)$ & $3.71(1.01)$ \\
\hline $13-18$ & $156(25)$ & $8.6(2.3)$ & $26.0(6.4)$ & $3.75(1.03)$ \\
\hline$\geq 19$ & $142(23)$ & $8.8(2.4)$ & $26.4(6.8)$ & $3.64(1.00)$ \\
\hline \multicolumn{5}{|l|}{ Child's nutritional statusI] } \\
\hline Adequate & 334 (59) & $8.6(2.3)$ & $25.7(6.4)$ & $3.72(1.01)$ \\
\hline Stunted & $135(24)$ & $8.6(2.4)$ & $26.0(7.0)$ & $3.63(1.08)$ \\
\hline Wasted & 78 (14) & $8.5(2.1)$ & $25.9(5.7)$ & $3.67(0.90)$ \\
\hline Stunted and wasted & $21(4)$ & $8.2(2.2)$ & $24.0(7.0)$ & 3.33 (1.19) \\
\hline \multicolumn{5}{|l|}{ Malaria } \\
\hline No & $389(74)$ & $8.9(2.1)$ & $26.9(6.1)$ & $3.87(0.95)$ \\
\hline Yes & $135(26)$ & $7.5(2.2) \dagger$ & $22.6(6.2) \dagger$ & $3.13(0.94) \dagger$ \\
\hline \multicolumn{5}{|l|}{ HIV $\S$ status } \\
\hline Negative & $543(91)$ & $8.6(2.3)$ & $25.7(6.5)$ & $3.68(1.02)$ \\
\hline Positive & 52 ( 9) & $8.2(2.1)$ & $25.1(6.1)$ & $3.53(0.94)$ \\
\hline \multicolumn{5}{|l|}{ Treatment group } \\
\hline Placebo & $307(50)$ & $8.5(2.2)$ & $25.7(6.1)$ & $3.68(0.96)$ \\
\hline Vitamin A & $310(50)$ & $8.6(2.3)$ & $25.9(6.8)$ & $3.68(1.06)$ \\
\hline
\end{tabular}

malaria, and age greater than 2 years at enrollment were associated with the development of severe anemia after four to eight months of follow-up. Infection with HIV was a strong predictor of low hemoglobin levels during follow-up.

Our results are consistent with those from cross-sectional surveys that have related low socioeconomic status to decreased hemoglobin levels in women of reproductive age and preschool children. In India, among pregnant women attending urban health centers, those with ten or more years of education had significantly higher mean hemoglobin concentration than those with less than 9 years, ${ }^{18}$ and among urban school children, there was a monotonic increase in mean hemoglobin by five categories of social class, from 8 $\mathrm{g} / \mathrm{dL}$ in the lowest to $13 \mathrm{~g} / \mathrm{dL}$ in the highest one. ${ }^{19}$ The prev- 
TABLE 3

Determinants of hemoglobin levels at baseline

\begin{tabular}{|c|c|c|c|}
\hline & No. & $\begin{array}{c}\text { Multivariate adjusted } \\
\text { hemoglobin difference }(\mathrm{g} / \mathrm{dL}) \\
\text { between groups }(95 \% \mathrm{CI})^{*}\end{array}$ & $\begin{array}{l}P \text { for } \\
\text { trend } \dagger\end{array}$ \\
\hline \multicolumn{4}{|l|}{ Sex } \\
\hline Male & 288 & Reference & \\
\hline Female & 234 & $0.32(-0.04,0.67)$ & \\
\hline \multicolumn{4}{|l|}{ Age (months) } \\
\hline $6-11$ & 221 & Reference & \\
\hline $12-23$ & 180 & $-0.20(-0.64,0.61)$ & \\
\hline$\geq 24$ & 122 & $0.38(-0.39,1.15)$ & 0.21 \\
\hline \multicolumn{4}{|l|}{ Mother's education } \\
\hline Low $\ddagger$ & 89 & Reference & \\
\hline Elementary & 404 & $-0.61(-1.07,-0.15)$ & \\
\hline Secondary & 29 & $0.96(0.10,1.82)$ & 0.13 \\
\hline \multicolumn{4}{|l|}{ Household possessions } \\
\hline 0 & 69 & Reference & \\
\hline 1 & 252 & $0.48(-0.03,1.00)$ & \\
\hline$\geq 2$ & 201 & $0.62(0.06,1.19)$ & 0.04 \\
\hline \multicolumn{4}{|l|}{ Water supply } \\
\hline Tap in house & 92 & $1.20(0.26,2.13)$ & \\
\hline Tap in compound & 154 & $0.74(-0.12,1.61)$ & \\
\hline Tap outside compound & 248 & $1.03(0.19,1.87)$ & \\
\hline Public well & 28 & Reference & \\
\hline \multicolumn{4}{|l|}{ Breastfeeding (months) } \\
\hline $0-6$ & 75 & Reference & \\
\hline $7-12$ & 196 & $0.17(-0.37,0.71)$ & \\
\hline $13-18$ & 130 & $0.32(-0.48,1.12)$ & \\
\hline$\geq 19$ & 121 & $0.33(-0.52,1.18)$ & 0.38 \\
\hline \multicolumn{4}{|l|}{ Malaria } \\
\hline No & 387 & Reference & \\
\hline Yes & 135 & $-1.31(-1.74,-0.88)$ & \\
\hline
\end{tabular}

* Coefficients from a linear regression model in which the effect of each variable is controlled for that of the others presented in the table. $95 \% \mathrm{CI}=95 \%$ confidence interval. $\dagger P$ value, test for trend, when the variable is introduced into the model as continuous. $\ddagger$ See definitions, Table 1 footnotes.

alence of mild, moderate, and severe anemia in children under five was also lowest among those from mothers with higher level of education in the Central Asian republics of Kazakstan, Uzbekistan, and Kyrgyz. ${ }^{20}$ Low socioeconomic status (SES), defined as the absence of a refrigerator and television in the household, was associated with significantly lower average hematocrit levels among children 6 to 59 months of age, admitted to an emergency ward in Kinshasa, Zaire. ${ }^{21}$ Other socioeconomic indicators that have been identified as independent risk factors for anemia include the percentage of outcome income spent in food, the quality of water supply and sewage, house ownership, ${ }^{22}$ and maternal height. ${ }^{23}$ Low SES is likely to reflect nutritional deficits including marginal intake of foods rich in highly bioavailable iron, poor sanitary practices, and recurrence of infectious diseases.

Previous studies have suggested that malaria is an important risk factor for the development of severe, life-threatening anemia in hyperendemic areas. Most of these studies have reported simultaneous associations between elevated parasitemia or clinical manifestations of malaria and low hemoglobin or hematocrit levels, ${ }^{21,24-28}$ but have failed to estimate the effect of time-varying patterns of malaria on hematologic parameters. Additional indirect evidence arises from studies of interventions aimed at reducing the incidence of malaria, that have proven effective in diminishing the risk of anemia. ${ }^{4,29}$ In a group of Tanzanian infants, the administration of malaria prophylactic treatment every week resulted in a $57 \%$ reduction in the risk of a first episode of severe anemia (packed cell volume $<25 \%$ ). ${ }^{4}$ After controlling for a number of potential confounding variables, including the anemia status at the outset of the observation period, we found a 4-fold increased risk for development of anemia at the last visit among children who had a positive blood smear at both baseline and follow-up visits, as compared with children who were negative in both assessments. Children with positive parasitemia at baseline but not at follow-up had the lowest risk of anemia at the last visit. This could be attributed to the fact that malaria at any visit led to treatment of the infection. We were unable to differentiate whether a positive blood smear at follow-up among children with baseline malaria was due to reinfection or to failure of the treatment. The physiopathologic mechanisms proposed to explain how malaria causes anemia include parasitic damage of erythrocytes and subsequent hemolysis mediated by complement, ${ }^{30,31}$ dyserythropoiesis, ${ }^{32,33}$ hypersplenism,,${ }^{34}$ and secondary folate deficiency. ${ }^{35}$ It was not possible for us to distinguish the effects of dietary-related iron deficiency on anemia from those of malaria infection. Both mechanisms are likely to interact, ${ }^{36}$ more so in a population with low intake of iron from the diet such as the one under study. ${ }^{5}$

Associations between breastfeeding and anemia have been reported from cross-sectional studies. Among Palestinian refugee children in their second year of life, the prevalence of anemia in those who had never been breastfed was $70 \%$ above that of children receiving breast milk at the time of the survey; ${ }^{37}$ however, no reference to length of breastfeeding was made. In our prospective study, duration of breastfeeding was strongly protective against the development of anemia during follow-up, after controlling for age and other potential confounding factors. All children had to be older than six months at enrollment and were receiving complementary foods at the time of recruitment. The maximum protective association was observed among children who were breastfed for more than 18 months. This is consistent with the fact that breast milk can be a readily available source of highly bioavailable iron (50\% as compared to $10 \%$ or less of iron from formula or cow's milk) ${ }^{38-40}$ in populations with poor-quality diets, even after six months of age. The length of breastfeeding assessed at the time of enrollment could be positively correlated with the iron stores of the baby, and thus children who had been breastfed for a longer period may have been protected against developing anemia during follow up. Similar conclusions can be drawn from reports of better iron status among children who have been exclusively breastfed for prolonged periods, when compared with non-breastfed children on poor iron diets. ${ }^{41}$ Breastfeeding alone, however, does not provide an adequate source of iron beyond the age of 6 months, ${ }^{42}$ and there is consensus regarding the need for supplementing the diet of exclusively breastfed children with iron after this age. ${ }^{43-46}$ In addition to providing bioavailable iron, breastfeeding may also lead to improved immunity, and hence to a reduced risk of malaria, which constitutes a potential explanation for the protective effect of breastfeeding on the development of anemia. Even though there is some transfer of antimalarial antibodies from mother to child through breast milk, ${ }^{47}$ this type of passive immunity is thought to last less than one month. Breast milk may also have nonspecific enhancing functions on cellular immunity. ${ }^{48}$ 
TABLE 4

Predictors of anemia at follow-up*

\begin{tabular}{|c|c|c|c|c|c|}
\hline & \multirow[b]{2}{*}{ No. } & \multirow[b]{2}{*}{$\%$ with anemia } & \multirow{2}{*}{$\begin{array}{l}\text { Multivariate adjusted } \\
\text { prevalence ratio } \\
(95 \% \mathrm{CI}) \dagger\end{array}$} & \multicolumn{2}{|c|}{$\begin{array}{l}\text { Effect of vitamin A versus placebo } \\
\text { on anemia, within each category }\end{array}$} \\
\hline & & & & $\begin{array}{l}\text { Prevalence ratio } \\
\quad(95 \% \mathrm{CI})\end{array}$ & $P$ for interaction $\neq$ \\
\hline \multicolumn{6}{|l|}{ Sex } \\
\hline Male & 92 & 9.8 & 1.00 & $1.10(0.27-4.44)$ & \\
\hline Female & 69 & 13.0 & $1.14(0.50-2.57)$ & $0.56(0.16-2.02)$ & 0.22 \\
\hline \multicolumn{6}{|l|}{ Age (months) } \\
\hline 6-11 & 76 & 10.5 & 1.00 & $1.08(0.33-3.56)$ & \\
\hline $12-23$ & 54 & 11.1 & $2.82(0.87-9.13)$ & $0.92(0.18-4.66)$ & \\
\hline$\geq 24$ & 31 & 12.9 & $8.11(1.18-55.8) \S$ & $0.39(0.03-4.43)$ & 0.93 \\
\hline \multicolumn{6}{|c|}{ Breastfeeding (months) } \\
\hline $0-6$ & 22 & 22.7 & 1.00 & $1.35(0.11-16.7)$ & \\
\hline $7-12$ & 72 & 11.1 & $0.90(0.32-2.57)$ & $0.29(0.06-1.33)$ & \\
\hline 13-18 & 37 & 8.1 & $0.23(0.05-1.06)$ & $1.35(0.10-17.8)$ & \\
\hline$\geq 19$ & 30 & 6.7 & $0.14(0.02-0.93) \mathrm{d}$ & $0.74(0.06-8.92)$ & 0.10 \\
\hline \multicolumn{6}{|l|}{ Malaria } \\
\hline Never & 60 & 11.7 & 1.00 & $0.89(0.27-2.95)$ & \\
\hline $\begin{array}{l}\text { Baseline, not fol- } \\
\text { low-up }\end{array}$ & 21 & 4.8 & $0.30(0.04-1.95)$ & $1.07(0.06-18.1)$ & \\
\hline $\begin{array}{l}\text { Follow-up, not } \\
\text { baseline }\end{array}$ & 20 & 15.0 & $0.90(0.26-3.14)$ & $0.68(0.10-4.81)$ & \\
\hline Always & 10 & 50.0 & $4.14(1.26-13.5)$ & $1.64(0.26-10.2)$ & 0.75 \\
\hline \multicolumn{6}{|l|}{ Anemia at baseline } \\
\hline No & 121 & 9.9 & 1.00 & $1.34(0.41-4.32)$ & \\
\hline Yes & 40 & 15.0 & $1.06(0.37-3.06)$ & $0.27(0.03-2.19)$ & 0.07 \\
\hline \multicolumn{6}{|l|}{ Treatment } \\
\hline Placebo & 80 & 12.5 & 1.00 & & \\
\hline Vitamin A & 81 & 9.9 & $0.86(0.37-1.99)$ & & \\
\hline
\end{tabular}

In populations where the limiting factor for anemia is a diminished dietary intake of iron, the prevalence of iron deficiency peaks at ages 6 to 12 months or 1 to 2 years, when more than $50 \%$ of the requirements arise from the accelerated growth velocity. ${ }^{49}$ In our study, the risk of severe anemia at the last visit was unexpectedly greater for children of 2 years or older. A direct association between malaria and age is not likely an explanation, since the prevalence of malaria actually decreased with age in this group (15\% in children of 2 years or older versus $25 \%$ before 24 months), similar to that described in other settings. ${ }^{25,50}$ In some populations, however, the fall in malaria prevalence occurs only after 36 months of age. ${ }^{28,51}$ In low SES areas where short spacing between gestations is prevalent, older children may be introduced to diets low in bioavailable iron or that interfere with iron absorption, such as cow's milk, ${ }^{52}$ as priority of care is given to newborns. An alternative explanation is that the increased prevalence for anemia after 2 years of age may be an indicator of persistent anemia after treatment of malaria, due to prolonged immune response mediated by $\mathrm{T}$ cells and lingering macrophage activation. ${ }^{53}$

We found a nonsignificant protective effect of vitamin A supplements on the risk of developing anemia over time, which appeared to be stronger among children who were severely anemic at the time of administration of the first supplement dose. The $14 \%$ risk reduction we found may represent an underestimation of the real effect of vitamin A on anemia, due to lack of compliance with the third and fourth doses by a group of children. It is also possible that we lacked statistical power to demonstrate a significant effect. In a population likely to suffer from combined vitamin A and iron deficiencies, vitamin A could help reduce the risk of anemia through several mechanisms. ${ }^{54,55}$ Recovery from anemia in the short term (before 2 months) after treatment with vitamin A has been documented previously in supplementation trials..$^{7-9,56}$ In an intervention study conducted among anemic, pregnant women from Indonesia, ${ }^{9}$ it was found that $35 \%$ out of those receiving daily doses of $2.4 \mathrm{mg}$ retinol became non-anemic (hemoglobin $>11 \mathrm{~g} / \mathrm{dL}$ ) after 8 weeks, as compared to only $16 \%$ in the placebo group, a 54\% risk reduction. Anemic preschool children from Guatemala who received $3 \mathrm{mg}$ of vitamin A per day for a period of two months experienced a higher increase in hemoglobin levels than those given placebo (0.93 versus $0.32 \mathrm{~g} / \mathrm{dL}$, respectively). ${ }^{7}$ Similar effects were found with the administration of single doses of the vitamin to anemic preschool children from Indonesia $(60 \mathrm{mg}$ retinol equivalent $)^{8}$ and to non-anemic children from Thailand $(110 \mathrm{mg}$ of vitamin A) $)^{56}$ after 8 and 2 weeks of follow-up, respectively. A plausible explanation for rapid responses of hemoglobin to the administration of vitamin $\mathrm{A}$ is that the vitamin prevents the inhibitory effect of phytates and polyphenols on the absorption of nonheme iron from diet. ${ }^{57,58}$ Other trials addressing fortification of foods with vitamin A have also resulted in long-term improvements of hematologic parameters in preschool children. ${ }^{59,60}$ The pathophysiology of a sus- 
tained, longer-term effect of vitamin A on hemoglobin levels is still unknown. Potential mechanisms include a direct effect of vitamin A or its metabolites on the differentiation of red cells. ${ }^{61}$ An indirect enhancement of erythropoiesis is also possible, by increasing the re-utilization of serum and reticulo-endothelial iron, which can be trapped during vitamin A deficiency. ${ }^{62}$ Finally, the modulating properties of vitamin A on immune responses during infection could play a role, which would result in the resumption of transferrin production, a protein down-regulated during the acute phase response. ${ }^{63}$

We found an association between HIV infection and decreased hemoglobin levels over time. The development of anemia during HIV disease in children is multifactorial. In this population, it may be the result of an impairment in iron absorption and subsequent iron deficiency, compromised hematopoiesis, and the presence of opportunistic infections. ${ }^{64,65}$ Anemia prevalence among HIV-infected children varies with underlying conditions, but is usually high, ranging from $12 \%$ to $94 \% .{ }^{66-68}$ Moreover, anemia is a prognostic factor for negative outcomes such as progression to AIDS and early death; $; 6,69$ thus, controlling preventable causes of anemia could also help reduce the burden of HIV-related morbidity and mortality.

In conclusion, the predictors of low hemoglobin levels and severe anemia in this population are largely modifiable conditions, including poor socioeconomic status, malaria, and HIV infection, and short duration of breastfeeding. Public health actions aimed at enhancing the level of maternal education and fostering breastfeeding practices, improving the quality of water supply, and preventing malaria, HIV, and other infectious diseases are likely to significantly reduce the burden of anemia among children from sub-Saharan Africa.

Acknowledgments: We thank the field staff and the mothers and children who made this study possible.

Financial support: This study was supported by the Thrasher Research Fund and the International Development Research Center. Astra Pharmaceuticals provided the raw material for the experimental regimens.

Authors' addresses: Eduardo Villamor and Wafaie Fawzi, Department of Nutrition, Harvard School of Public Health, 665 Huntington Avenue-SPH 2, Boston, MA 02115. Roger Mbise, Department of Pediatrics and Child Health, Muhimbili University College of Health Sciences, Dar es Salaam, Tanzania. Donna Spiegelman, Department of Epidemiology, Harvard School of Public Health, 665 Huntington Avenue, Boston, MA 02115. Godwin Ndossi, Tanzania Food and Nutrition Center, Dar es Salaam, Tanzania.

\section{REFERENCES}

1. United Nations Administrative Committee on Coordination/ Subcommittee on Nutrition (ACC/SCN), 1997. Third Report on the World Nutrition Situation. Geneva: World Health Organization.

2. Gillespie S, 1998. Major Issues in the Control of Iron Deficiency. The Micronutrient Initiative. New York: UNICEF.

3. Stoltzfus RJ, Albonico M, Chwaya HM, Tielsch JM, Schulze KJ, Savioli L, 1998. Effects of the Zanzibar school-based deworming program on iron status of children. Am J Clin Nutr 68: $179-186$.

4. Menendez C, Kahigwa E, Hirt R, Vounatsou P, Aponte JJ, Font F, Acosta CJ, Schellenberg DM, Galindo CM, Kimario J, Urassa $\mathrm{H}$, Brabin B, Smith TA, Kitua AY, Tanner M, Alonso PL, 1997. Randomised placebo-controlled trial of iron sup- plementation and malaria chemoprophylaxis for prevention of severe anemia and malaria in Tanzanian infants. Lancet 350: $844-850$

5. Tatala S, Svanberg U, Mduma B, 1998. Low dietary iron availability is a major cause of anemia: a nutrition survey in the Lindi District of Tanzania. Am J Clin Nutr 68: 171-178.

6. Bloem MW, 1995. Interdependence of vitamin A and iron: an important association for programmes of anaemia control. Proc Nutr Soc 54: 501-508.

7. Mejia LA, Chew F, 1988. Hematological effect of supplementing anemic children with vitamin $\mathrm{A}$ alone and in combination with iron. Am J Clin Nutr 48: 595-600.

8. Semba RD, Muhilal, West KP, Winget M, Natadisastra G, Scott A, Sommer A, 1992. Impact of vitamin A supplementation on hematological indicators of iron metabolism and protein status in children. Nutr Res 12: 469-478.

9. Suharno D, West CE, Muhilal, Karyadi D, Hautvast, JGAJ, 1993. Supplementation with vitamin A and iron for nutritional anaemia in pregnant women in West Java, Indonesia. Lancet 342: $1325-1328$.

10. Suharno D, Muhilal, 1996. Vitamin A and nutritional anemia. Food Nutr Bull 17: 7-10.

11. Fawzi W, Mbise R, Fataki M, Herrera M, Kawau F, Hertzmark E, Spiegelman D, Ndossi G, 1998. Vitamin A supplementation and severity of pneumonia in children admitted to the hospital in Dar es Salaam, Tanzania. Am J Clin Nutr 68: 187192.

12. Fawzi WW, Mbise RL, Hertzmark E, Fataki MR, Herrera MG, Ndossi G, Spiegelman D, 1999. A randomized trial of vitamin A supplements in relation to mortality among HIV infected and uninfected children in Tanzania. Pediatr Infect Dis J 18: 127-133.

13. Dacie JV, Lewis SM, 1994. Practical Haematology. London: Churchill-Livingstone.

14. Diggle PJ, Liang KY, Zeger SL, 1994. Analysis of Longitudinal Data. Oxford: Clarendon Press.

15. White H, 1980. A heteroskedasticity-consistent covariance matrix estimator and a direct test for heteroskedasticity. Econometrica 48: 817-830.

16. Stoltzfus RJ, Chwaya HM, Tielsch JM, Schulze KJ, Albonico M, Savioli L, 1997. Epidemiology of iron deficiency anemia in Zanzibari schoolchildren: the importance of hookworms. Am J Clin Nutr 65: 153-159.

17. Wacholder S, 1986. Binomial regression in GLIM: estimating risk ratios and risk differences. Am J Epidemiol 123: 174184.

18. Brabin L, Nicholas S, Gogate A, Gogate S, Karande A, 1998. High prevalence of anaemia among women in Mumbai, India. Food Nutr Bull 19: 205-209.

19. Verma M, Chhatwal J, Kaur G, 1998. Prevalence of anemia among urban school children of Punjab. Indian Pediatrics 35: $1181-1186$.

20. Sharmanov A, 1998. Anaemia in Central Asia: demographic and health survey experience. Food Nutr Bull 19: 307-317.

21. Hedberg K, Shaffer N, Davachi F, Hightower A, Lyamba B, Mbudi Paluku K, Nguyen-Dinh P, Breman JG, 1993. Plasmodium falciparum-associated anemia in children at a large urban hospital in Zaire. Am J Trop Med Hyg 48: 365-371.

22. Johnson AA, Latham MC, Roe DA, 1982. The prevalence and the etiology of the nutritional anemias in Guyana. Am J Clin Nutr 35: 309-318.

23. Redd SC, Wirima JJ, Steketee RW, 1994. Risk factors for anemia in young children in rural Malawi. Am J Trop Med Hyg 51: $170-174$.

24. Greenwood BM, Bradley AK, Greenwood AM, Byass P, Jammeh K, Marsh K, Tulloch S, Oldfield FSJ, Hayes R, 1987. Mortality and morbidity from malaria among children in a rural area of The Gambia, West Africa. Trans $R$ Soc Trop Med Hyg 81: 478-486.

25. Premji Z, Hamisi Y, Shiff C, Mijas J, Lubega P, Cyprian M, 1995. Anaemia and Plasmodium falciparum infections among young children in an holoendemic area, Bagamoyo, Tanzania. Acta Tropica 59: 55-64.

26. Akum Achidi E, Samusa Salimonu L, Asuzu MC, Berzins K, 
Walker O, 1996. Studies on Plasmodium falciparum parasitemia and development of anemia in Nigerian infants during their first year of life. Am J Trop Med Hyg 55: 138-143.

27. Newton CRJC, Warn PA, Winstanley PA, Peshu N, Snow RW, Pasvol G, Marsh K, 1997. Severe anaemia in children living in a malaria endemic area of Kenya. Trop Med Int Health 2: 165-178.

28. Cornet M, Le Hesran JY, Fievet N, Cot M, Personne P, Gounque R, Beyeme M, Deloron P, 1998. Prevalence of and risk factors for anemia in young children in Southern Cameroon. Am J Trop Med Hyg 58: 606-611.

29. Shiff C, Checkley W, Winch P, Premji Z, Minjas J, Lubega P, 1996. Changes in weight gain and anemia attributable to malaria in Tanzanian children living under holoendemic conditions. Trans R Soc Trop Med Hyg 90: 262-265.

30. Hercberg S, Chauliac M, Galan P, Devanlay M, Zohoun I, Agboton Y, Soustre Y, Bories C, Christides JP, Potier de Courcy G, 1986. Relationship between anaemia, iron and folacin deficiency, haemoglobinopathies and parasitic infection. Hum Nut Clin Nutr 40: 371-379.

31. Abdalla SH, Weatherall DJ, 1982. The direct antiglobulin test in P. falciparum malaria. Br J Haematol 51: 415.

32. Crompton DWT, 1986. Nutritional aspects of infection. Trans $R$ Soc Trop Med Hyg 80: 697-705.

33. Abdalla SH, Weatherall DJ, Wickaramsinghe SN, Hughes M, 1980. The anemia of $P$. falciparum malaria. $\mathrm{Br} J$ Haematol 46: 171.

34. Kasili EG, 1990. Malnutrition and infections as causes of childhood anemia in tropical Africa. Am J Pediatr Hematol Oncol 12: $375-377$.

35. Serjeant GR. 1985. Sickle Cell Disease. Oxford: Oxford University Press.

36. Smith AW, Hendrickse RG, Harrison C, Hayes RJ, Greenwood BM, 1989. The effects on malaria of treatment of iron-deficiency anemia with oral iron in Gambian children. Ann Trop Paediatr 9: 17-23.

37. Hassan K, Sullivan KM, Yip R, Bradley AW, 1997. Factors associated with anemia in refugee children. J Nutr 127: 2194 2198.

38. Saarinen UM, Siimes MA, Dallman PR, 1977. Iron absorption in infants: high bioavailability of breast milk iron as indicated by extrinsic tab method of iron absorption and by the concentration of serum ferritin. J Pediatr 91: 36-39.

39. McMillan JA, Landaw SA, Oski FA, 1976. Iron sufficiency in breast-fed infants and the availability of iron from human milk. Pediatrics 58: 686-691.

40. Centers for Disease Control and Prevention, 1998. Recommendations to prevent and control iron deficiency in the United States. MMWR 47: 4

41. Pisacane A, De Vizia B, Valiante A, Vaccaro F, Russo M, Grillo G, Giustardi A, 1995. Iron status in breast-fed infants. $J$ Pediatr 127: 429-431.

42. Siimes MA, Vuori E, Kuitunen P, 1979. Breast milk iron-a declining concentration during the course of lactation. Acta Paediatr Scand 68: 29-31.

43. Duncan B, Schifman RB, Corrigan JJ, Schaefer C, 1985. Iron and the exclusively breast-fed infant from birth to six months. J Pediatr Gastroenterol Nutr 4: 421-425.

44. Iwai Y, Takanashi T, Nakao Y, Mikawa H, 1986. Iron status in low birth weight infants on breast and formula feeding. Eur J Pediatr 145: 63-65.

45. Pizarro F, Yip R, Dallman PR, Olivares M, Hertrampf E, Walter T, 1991. Iron status with different infant feeding regimens: relevance to screening and prevention of iron deficiency. $J$ Pediatr 118: 687-692.

46. Siimes MA, Salmenpera L, Perheentupa J, 1984. Exclusive breast-feeding for 9 months: risk of iron deficiency. $J$ Pediatr 104: 196-199.

47. Omanga U, Kageruka P, Tshishimbi M, 1982. Immunite antipaludique materno-transmise et son evolution chez l'enfant. Med Trop 42: 19-25.
48. Ogra SS, Weintraub D, Ogra PL, 1977. Immunologic aspects of human colostrum and milk. III. Fate and absorption of cellular and soluble components in the gastrointestinal tract of the newborn. J Immunol 119: 245-248.

49. FAO/WHO (Food and Agriculture Organization/World Health Organization), 1988. Requirements of Vitamin A, Iron, Folate and Vitamin B12. Food and Nutrition Series 23. Rome: FAO.

50. Akenzua GI, Ihongbe JC, Imasuen IW, Nwobi BC, 1985. Anaemia in children: a survey in (Obadan) a rural community in the rain forest zone of Nigeria. J Trop Pediatr 31: 20-24.

51. Nicklas TA, Kuvibidila S, Gatewood LC, Metzinger AB, Frempong KO, 1998. Prevalence of anaemia and iron deficiency in urban Haitian children two to five years of age. J Trop Pediatr 44: 133-138.

52. Hurrell RF, Lynch SR, Trinidad TP, Dassenko SA, Cook JD 1989. Iron absorption in humans as influenced by bovine milk proteins. Am J Clin Nut 49: 546-552.

53. Biemba G, Gordeuk VR, Thuma PE, Mabeza GF, Weiss G 1998. Prolonged macrophage activation and persistent anaemia in children with complicated malaria. Trop Med Int Health 3: 60-65.

54. Hodges R, Sauberlich H, Canham J, Wallace D, Rucker R, Mejia L, Mohanram M, 1978. Hematopoietic studies in vitamin A deficiency. Am J Clin Nutr 31: 876-885.

55. Mejia LA, Hodges RE, Arroyave G, Viteri F, Torun B, 1977. Vitamin A deficiency and anemia in Central American children. Am J Clin Nutr 30: 1175-1184.

56. Bloem MW, Wedel M, van Agtmaal EJ, Speek AJ, Saowakontha S, Schreurs WHP, 1990. Vitamin A intervention: short-term effects of a single, oral, massive dose on iron metabolism. Am J Clin Nutr 51: 76-79.

57. Garcia-Casal M, Layrisse M, Solano L, Baron M, Arguello F, Llovera D, Ramirez J, Leets I, Tropper E, 1998. Vitamin A and beta-carotene can improve nonheme iron absorption from rice, wheat and corn by humans. J Nutr 128: 646-650.

58. Layrisse M, García-Casal MN, Solano L, Barón MA, Arguello F, Llovera D, Ramírez J, Leets I, Tropper E, 1998. Vitamin A reduces the inhibition of iron absortion by phytates and polyphenols. Food Nutr Bull 19: 3-5.

59. Muhilal, Permeisih D, Idjradinata YR, Muherdiyantiningsih., Karyadi D, 1988. Vitamin A-fortified monosodium glutamate and health, growth, and survival of children: a controlled field trial. Am J Clin Nutr 48: 1271-1276.

60. Mejia LA, Arroyave G, 1982. The effect of vitamin A fortification of sugar on iron metabolism in preschool children in Guatemala. Am J Clin Nutr 36: 87-93.

61. Douer D, Koeffler HP, 1982. Retinoic acid enhances growth of human early erythroid progenitor cells in vitro. J Clin Invest 69: 1039-1041

62. Staab DB, Hodges RE, Metcalf WK, Smith JL, 1984. Relationship between vitamin A and iron in the liver. $J$ Nutr 114 . 840-844.

63. Thurnham DI, 1993. Vitamin A, Fe, and haemopoiesis (editorial). Lancet 342: 1312-1313.

64. Ellaurie M, Rubinstein A, 1995. Elevated tumor necrosis factoralpha in association with severe anemia in human immunodeficiency virus infection and Mycobacterium avium intracellulare infection. Pediatr Hematol Oncol 12: 221-230.

65. Sirisanthana V, Sirisanthana T, 1995. Disseminated Penicillium marneffei infection in human immunodeficiency virus-infected children. Pediatr Infect Dis J 14: 935-940.

66. Ellaurie M, Burns ER, Rubinstein A, 1990. Hematologic manifestations in pediatric HIV infection: severe anemia as a prognostic factor. Am J Pediatr Hematol Oncol 12: 449-453.

67. Vetter KM, Djomand G, Zadi F, Diaby L, Brattegaard K, Timite M, Andoh J, Adou JA, De Cock KM, 1996. Clinical spectrum of human immunodeficiency virus disease in children in a West African city. Pediatr Infect Dis J 15: 438-442.

68. Hilgartner M, 1991. Hematologic manifestations of HIV-infected children. J Pediatr 119: S47-S49.

69. Moore RD, 1999. Human immunodeficiency virus infection, anemia, and survival Clin Infect Dis 29:44-49. 